\title{
AUSTROPEDIOMYS MARSHALLI GEN. ET SP. NOV., A NEW PEDIOMYOIDEA (MAMMALIA, METATHERIA) FROM THE PALEOGENE OF BRAZIL: PALEOBIOGEOGRAPHIC IMPLICATIONS
}

\author{
LEONARDO M. CARNEIRO \\ Laboratório de Paleontologia (PALEOLAB), Departamento de Geologia, Centro de Tecnologia e Geociências, \\ Universidade Federal de Pernambuco. Av. Acadêmico Hélio Ramos s/n, 50740-530, Recife, PE, Brazil. \\ leonardo.carneiro8@gmail.com \\ ÉDISON V. OLIVEIRA \\ Laboratório de Paleontologia (PALEOLAB), Departamento de Geologia, Centro de Tecnologia e Geociências, \\ Universidade Federal de Pernambuco. Av. Acadêmico Hélio Ramos s/n, 50740-530, Recife, PE, Brazil. \\ vicenteedi@gmail.com
}

FRANCISCO J. GOIN

MORPHOS Lab y División Paleontología Vertebrados, Facultad de Ciencias Naturales y Museo de La Plata (UNLP), Paseo del Bosque s/n, B1900FWA La Plata. CONICET, Argentina. fgoin@fcnym.unlp.edu.ar

\begin{abstract}
The Pediomyiodea has been largely regarded as a Late Cretaceous North American metatherian lineage; however, some studies have suggested that a few South American taxa could be related to this family. Herein, Austropediomys marshalli gen. et sp. nov. from the Itaboraí Basin, Brazil (lower Eocene - Itaboraian SALMA), is described. Austropediomys gen. nov. represents the first report of a pediomyoid metatherian in the Paleogene of South America backed by a phylogenetic analysis. Several derived features in the upper molars support its belonging to the Pediomyoidea: presence of accessory 'conular-like' structures (here named conuloids) lingual to the conules; supernumerary stylar cusps; asymmetric stylar shelf, with parastylar shelf reduced to a narrow rim in M1; straight centrocrista; short and obliquely oriented prepacrista, which contacts StA in M2-3. The presence of 'conular-like' structures lingual to the paraconule and metaconule is identified in Austropediomys gen. nov. and in Late Cretaceous pediomyoids as well, and results in the phylogenetic analysis as a synapomorphy of the Pediomyoidea. Austropediomys gen. nov. is autapomorphyc in the presence of enlarged conuloids on protocristae. The record of a pediomyoid in the Paleogene of South America increases the temporal and biogeographical range of this lineage. Also, our results support the hypothesis that several non-related metatherian lineages dispersed from North to South America via the Caribbean Plate, most probably during the latest Cretaceous, in an island-hopping or sweepstakes model.
\end{abstract}

Keywords: Lower Eocene, Itaboraí Basin, Pediomyoidea, systematics.

RESUMO - Os Pediomyoidea sempre foram considerados como um grupo de metatérios norte-americanos do Cretáceo Superior. No entanto, alguns estudos sugeriram que alguns táxons sul-americanos poderiam estar relacionados com esse clado. Aqui, é descrito Austropediomys marshalli gen. et sp. nov. da Bacia de Itaboraí, Brasil (Eoceno inferior - SALMA Itaboraiense). Austropediomys gen. nov. representa o primeiro relato de um metatério do grupo dos pediomídeos no Paleógeno da América do Sul apoiado por uma análise filogenética. Várias características derivadas nos molares superiores sustentam sua inclusão no clado dos Pediomyoidea: presença de estruturas acessórias (aqui denominadas conuloides) linguais aos cônulos; cúspides estilares supranumerárias; plataforma estilar assimétrica, com o lobo parastilar reduzido a uma faixa estreita no M1; paracone arredondado e metacone piramidal no M1; centrocrista reta; prepacrista curta e obliquamente orientada, contactando StA em M2-3. A presença de estruturas conulares linguais ao paracônulo e metacônulo é identificada em Austropediomys gen. nov. e também em pediomioides do Cretáceo Superior, sendo recuperada na análise filogenética como uma sinapomorfia dos Pediomyoidea. Austropediomys gen. nov. é autapomórfico pela presença de conuloides evidentemente desenvolvidos na pré- e pós-protocrista. O registro de um pediomioide no Paleógeno da América do Sul aumenta a amplitude temporal e biogeográfica dessa linhagem. Além disso, nossos resultados suportam a hipótese de que várias linhagens de metatérios se dispersaram da América do Norte para a América do Sul através da Placa do Caribe, provavelmente durante o Cretáceo Superior, em um modelo similar ao sweepstakes ou 'saltos-de-ilhas' (island hopping).

Palavras-chave: Eoceno inferior, Bacia de Itaboraí, Pediomyoidea, sistemática. 


\section{INTRODUCTION}

The Pediomyoidea (Simpson, 1927), has been considered as an endemic metatherian lineage from the Upper Cretaceous of North America. The fossil record of this family is known from the upper Santonian to the uppermost Maastrichtian, with no confirmed record for the Cenozoic of that continent (Clemens, 1966; Eaton, 2006, 2013; Davis, 2007; Williamson et al., 2012, 2014; Wilson, 2014). Notwithstanding, possible pediomyioids have been reported for South America in: (i) the lower Paleocene of Tiupampa, Bolivia (Case \& Woodburne, 1986; Muizon, 1992; Oliveira \& Goin, 2012; Woodburne et al., 2014; Goin et al., 2016), (ii) Laguna Umayo, southern Peru (Sigé, 1972), currently dated as upper Paleocene-lower Eocene (Sigé et al., 2004; Gelfo \& Sigé, 2011); and (iii) the lower Eocene of Itaboraí Basin, Brazil (Marshall, 1987; Marshall et al., 1990; Oliveira, 1998; Oliveira \& Goin, 2012). Based on tarsal morphological elements, Szalay (1994) stated that the lower ankle joint of some specimens from Itaboraí (his "Itaboraí Metatherian Group 1" sample) "... are very similar to the peradectine and pediomyine patterns" (Szalay, 1994, p. 164). Nevertheless, a phylogenetic study including these South American taxa together with North American pediomyioids was still lacking.

Marshall (1987) and Marshall et al. (1990) identified as a Pediomyinae the Itaboraí genus Monodelphopsis Paula Couto, 1952, in a concept that considers this subfamily as belonging to Microbiotheriidae, along with Microbiotheriinae. Muizon (1992) suggested that the similarities between Khasia cordillerensis Marshall \& Muizon, 1988, Microbiotheriidae and Monodelphopsis could indicate close affinities between pediomyids and microbiotheriids. Later, Oliveira \& Goin (2011) supported the hypothesis of close affinities between microbiotheriids and pediomyids, but regarded Monodelphopsis as more closely related to Jaskhadelphyidae and not to Microbiotheria or Pediomyidae. Oliveira et al. (2016) got similar results for Monodelphopsis, though regarded the Microbiotheria as more closely related to Polydolopimorphia and Khasia as an independent lineage from Microbiotheria and Jaskhadelphyidae. Unfortunately, no pediomyid was included in the phylogenetic analyses of Oliveira \& Goin (2011) or Oliveira et al. (2016) in order to support the pediomyid affinities of Khasia, Microbiotheria and Monodelphopsis.

For Marshall (1987), the specimen DGM 808-M represents the upper dentition of Monodelphopsis travassosi. As shown below, the reanalysis of specimen DGM 808-M led to the conclusion that it does not belong to Monodelphopsis. Herein, it is described a new taxon for the Itaboraí Basin. The new taxon was included in a phylogenetic analysis in order to discuss its affinities in relation to North and South American lineages.

Institutional abbreviations. DNPM, Departamento Nacional de Produção Mineral, Rio de Janeiro, Brazil; MCT (ex DGM, Divisão de Geologia e Mineralogia), Museu de Ciências da Terra, Rio de Janeiro, Brazil; OMNH, Oklahoma Museum of Natural History, Norman, Oklahoma, USA; UALVP, University of Alberta Laboratory for Vertebrate Paleontology,
Edmonton, Alberta, Canada; UMMZ, Museum of Zoology, University of Michigan, USA.

Other abbreviations. $\mathbf{m}$, lower molars (numbers indicate their corresponding locus); $\mathbf{M}$, upper molars; $\mathbf{p}$, lower premolars; P, upper premolars; StA, stylar cusp A; StB, stylar cusp B; StC, stylar cusp C; StD, stylar cusp D; StE, stylar cusp E. NALMA, North American Land Mammal Age. SALMA, South American Land Mammal Age. SEM, Scanning Electron Microscope. Measurements are in millimeters $(\mathrm{mm})$.

\section{MATERIAL AND METHODS}

All specimens assigned to the new taxon are deposited at the Departamento de Produção Mineral (DNPM), Rio de Janeiro, Brazil. These specimens are from the Itaboraí Basin, São José de Itaboraí, Rio de Janeiro, Brazil (2245'9.9144”'S, $42^{\circ} 51^{\prime} 53.5536$ ”'W) (Figure 1).

The new data matrix is based on the characters published in Ladevèze \& Muizon (2010), Luo et al. (2011), Abello (2013), Forasiepi et al. (2015), Muizon et al. (2015), Wilson et al. (2016), Beck (2017), Carneiro \& Oliveira (2017a, b) and Carneiro (2018). The matrix is based on dental characters from upper and lower dentition, dentary, cranial and postcranial characters of fossil and living metatherians.

The character data set of the new taxon was elaborated through the analysis of the original materials, casts, and SEM pictures. Brazilian taxa, from Itaboraí Basin, in southeastern Brazil (Figure 1), were directly examined (i.e. fossil specimens

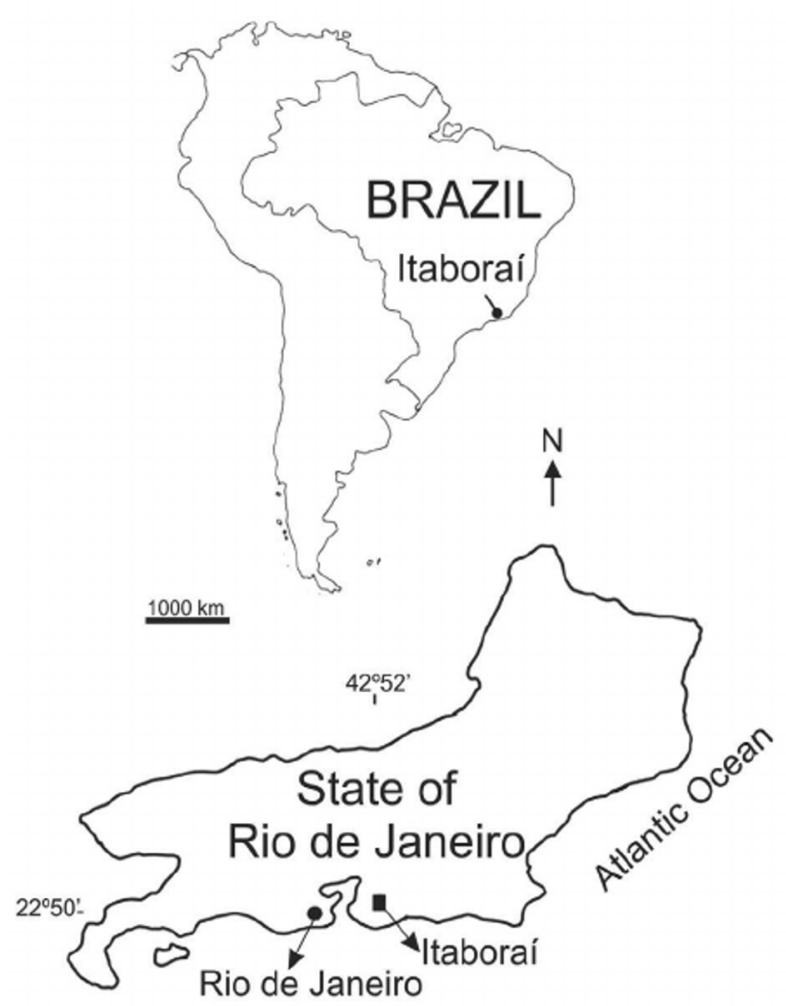

Figure 1. Location map showing the region and coordinates of the Itaboraí Basin, São José de Itaboraí, Rio de Janeiro, Brazil (2245'9.9144'”S, 4251'53.5536'”W). 
and casts); in addition, literature descriptions, casts, digital and SEM pictures were also analyzed. The North American and Argentinian taxa were studied based on its original descriptions and revisions, stereo and SEM pictures present in the literature (Clemens, 1966; Davis, 2007). The materials from Naturita (formerly Dakota) Formation (upper Cenomanian, Carpenter, 2014) were examined from casts and pictures. These casts were sent by Richard L. Cifelli and Joshua E. Cohen from the Sam Noble Oklahoma Museum of Natural History, USA. The list of casts is given in the supplementary material. The characters of Dromiciops were recovered based mainly from photos of UMMZ 155904, sent to us by Philip Myers, curator emeritus of mammals from the Museum of Zoology of the University of Michigan.

The SEM images of the new taxon were made with the Scanning Electron Microscope JEOL JSM-6390LV at the Centro de Microscopia Eletrônica de Varredura do Departamento de Invertebrados do Museu Nacional, Museu Nacional, Rio de Janeiro, Brazil. The phylogenetic analysis was performed using a new technology search with TNT 1.5 (Goloboff \& Catalano, 2016) using the sectorial, ratchet, drift and tree-fusing strategies with 500 replications. The morphological matrix is available as supplementary material. Bremer supports and tree scores were calculated with TNT 1.5. The phylogeny presents 642 unordered characters, including cranial, dentary, dental and postcranial characters, and 179 therian taxa, including more than 160 metatherians, from the Cretaceous and Cenozoic of North America and Asia, and of the Cenozoic of Gondwana.

\section{SYSTEMATIC PALEONTOLOGY}

MAMMALIA Linnaeus, 1758

METATHERIA Huxley, 1880

MARSUPIALIFORMES Vullo et al., 2009

†Order ARCHIMETATHERIA Szalay, 1994

$\dagger$ Superfamily PEDIOMYIODEA (Simpson, 1927)

$\dagger$ Austropediomys gen. nov.

urn:lsid:zoobank.org:act:1CB87D91-DAF3-4F24-94532C76C56F9DAC

1987 Monodelphopsis travassosi (part.) Marshall, p. 115, figs. 31-32.
Type species. Austropediomys marshalli sp. nov.

Etymology. From the Latin 'austro'=south; 'pediomys', in reference to its pediomyoid affinities.

Included species. The type only.

Diagnosis. Differs from other pediomyoids in the following combination of features: upper molars lacking winged conules; anterior cingulum reduced to the mesiolabial face of the paracone in M2-3; absence of metacingulum; paracone much lower and smaller than metacone; paracone pyramidal in shape while the metacone is rounded, and StB proportionally larger.

Locality and age. Fissure discovered and worked in 1968, of the Itaboraí Formation, Itaboraí Basin, municipality of Itaboraí, State of Rio de Janeiro, Brazil (Bergqvist et al., 2009). Lower Eocene, Itaboraian SALMA (ca. 53-50 Ma; sensu Woodburne et al., 2014).

Remarks. Austropediomys gen. nov. can be identified as a pediomyoid metatherian based on the presence of accessory 'conular-like' structures lingual to the para- and metaconule (here named conuloids - see 'Discussion' for more details), short and obliquely oriented preparacrista, which contacts the StA; asymmetric stylar shelf in M1-2, supernumerary cusp between StA and StB, protoconal expansions and straight centrocrista. As a result of the phylogenetic analysis, the new taxon herein described is recovered as the sister group of the Pediomyidae (see below).

$\dagger$ Austropediomys marshalli sp. nov.

(Figures 2-4)

1987 Monodelphopsis travassosi (part.) Marshall, p. 115, figs. 31-32.

Holotype. DGM 808-M, incomplete left maxilla with M2-4 (Figure 2).

Hypodigm. MCT 2798-M, incomplete left M1 (Figure 3B); MCT 2799-M, complete left M3 (Figure 3C1-2); MCT 2800$\mathrm{M}$, incomplete right M4 (Figure 3A1-3); MCT 4386-M, left DP3 (Figure 4).

Etymology. marshalli, after the North American paleontologist Larry G. Marshall, in recognition to his numerous contributions to the knowledge of extinct South American metatherians.

Locality and age. As for the genus.

Diagnosis. As for the genus.

Measurements. See Table 1.

Table 1. Measurements (mm) of the upper molars of Austropediomys marshalli gen. et sp. nov. Length, mesiodistal axis; width, labiolingual axis.

\begin{tabular}{|c|c|c|c|c|c|c|c|c|c|c|}
\hline & $\begin{array}{c}\text { DP3 } \\
\text { length }\end{array}$ & $\begin{array}{c}\text { DP3 } \\
\text { width }\end{array}$ & M1 length & M1 width & M2 length & M2 width & M3 length & M3 width & M4 length & M4 width \\
\hline DGM 808-M & & & & & 1.98 & 2.48 & 1.89 & 2.73 & 1.61 & 2.75 \\
\hline MCT 2798-M & & & 1.98 & 2.01 & & & & & & \\
\hline МCT 2799-M & & & & & & & 1.91 & 2.71 & & \\
\hline МCT 2800-M & & & & & & & & & 2.02 & 2.59 \\
\hline МСТ 4386-M & 1.83 & 1.58 & & & & & & & & \\
\hline
\end{tabular}



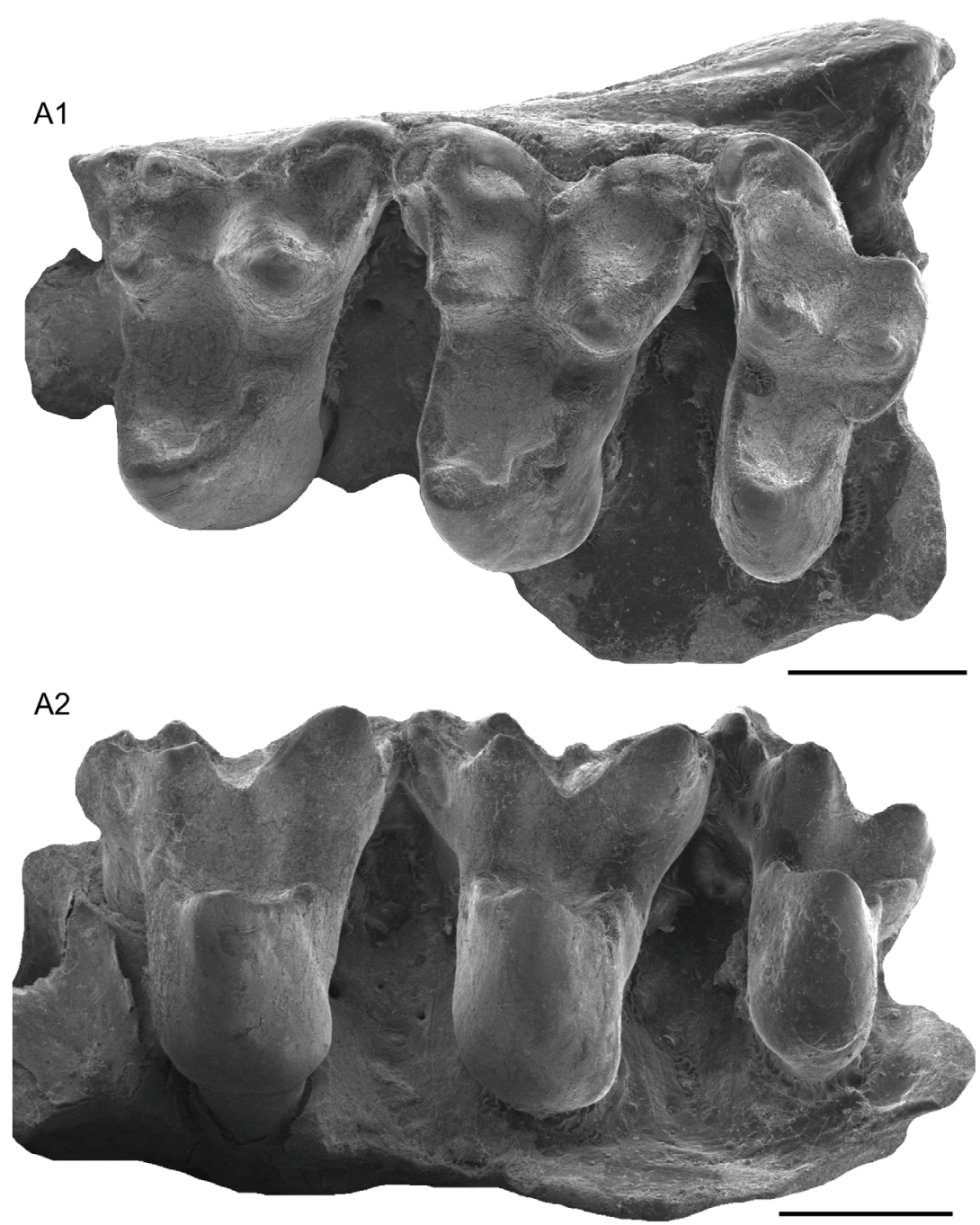

Figure 2. Type specimen of Austropediomys marshalli gen. et sp. nov. SEM pictures of DGM 808-M, a maxilla fragment with M2-4 in occlusal view (A1) and lingual view (A2). Scale bars $=1 \mathrm{~mm}$.

Description. The DP3 (MCT 4386-M) shows markedly labiolingually compressed talon and protocone, reduced protoconal basal expansions, centrally placed protocone, vestigial conules and conuloids, straight centrocrista, rounded paracone and pyramidal metacone; paracone slightly larger than metacone, judging by the bases size; preparacrista oriented to StA, vestigial StB, labial cuspules keel, with weakly developed $\mathrm{StC}$ and $\mathrm{StD}$; StA as the largest stylar cusp, metastylar lobe broader than parastylar lobe, reduced paracingulum and metacingulum absent (Figure 4). This tooth is identified as a DP3 based on the presence of vestigial parastylar lobe of stylar shelf, vestigial StB, centrally placed protocone, and rounded and inflated paracone. The M1 (MCT 2798-M) shows weakly developed basal expansions of protocone; parastylar shelf reduced to a narrow rim, as a consequence, the stylar shelf is asymmetric, with the metastylar lobe wider than the parastylar one; stylar cusps are conical, reduced and aligned at the labial edge of the stylar shelf; StA is proportionally large, while $\mathrm{StB}$ and $\mathrm{StC}$ are moderately sized; $\mathrm{StB}$ is labiolingually compressed; $\mathrm{StB} 1$ is present at the distolabial border of $\mathrm{StB} ; \mathrm{StC}$ is mesiolingually oriented; the preparacrista is short and obliquely oriented to $\mathrm{StB}$; the paracingulum is complete; the ectoflexus is shallow; the paracone is pyramidal and smaller than the pyramidal metacone; the centrocrista is straight (i.e. aligned with the para- and metacone apices), the conules are reduced, the protocone is weakly inflated and the metacingulum is absent (Figure 3B). The M2 (DGM 808-M) is less mesiodistally compressed than M1 and M3; it shows a relatively large StB, reduced supernumerary stylar cusps, twinned $\mathrm{StC}$, flattened StD and StE; developed supernumerary cusp between StA and StB; asymmetric stylar shelf, with its metastylar portion broader than the parastylar one; the parastylar shelf is not reduced as in M1, deep ectoflexus, moderately developed preparacrista, which contacts the StA; pyramidal and slightly twisted paracone, rounded metacone, which is 

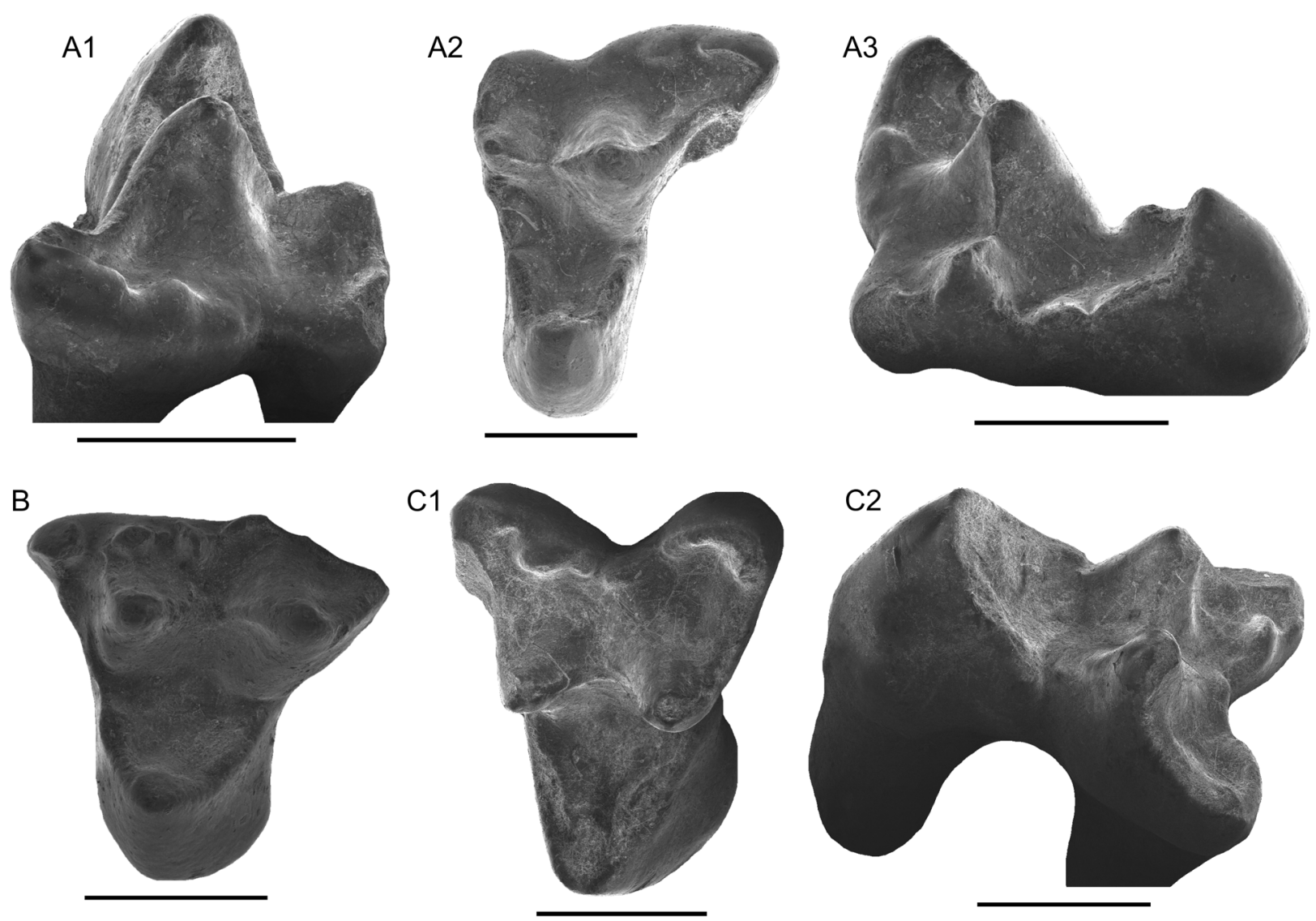

Figure 3. Isolated upper molars of Austropediomys marshalli gen. et sp. nov. MCT 2800-M, a RM4 in labial (A1), occlusal (A2) and distal (A3) views. MCT 2798-M, a LM1 in occlusal view (B). MCT 2799-M, a LM3 in occluso-labial (C1) and distal (C2) views. Scale bars $=1 \mathrm{~mm}$.

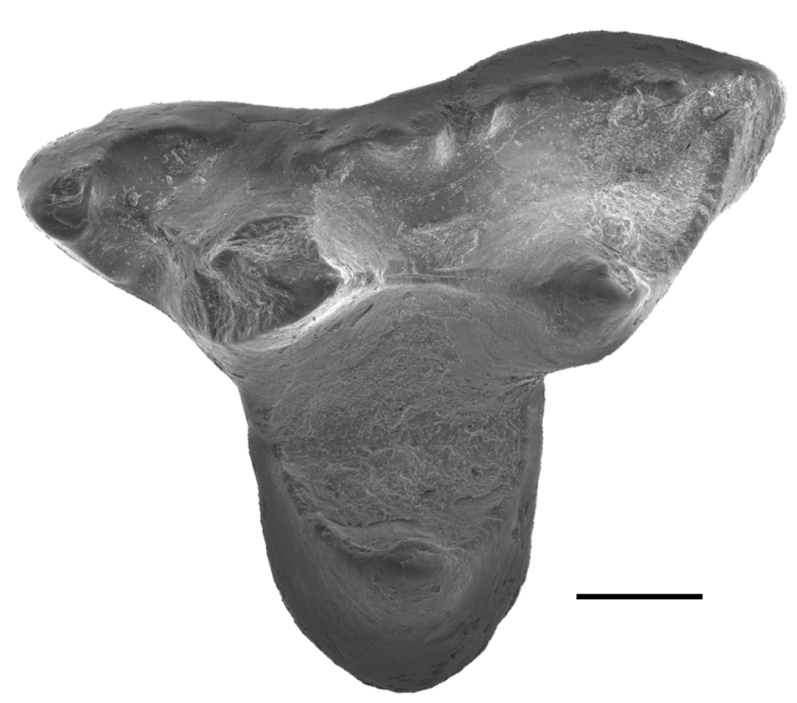

Figure 4. SEM micrograph of MCT 4386-M, LDP3 in occlusal view. Scale bar $=0.5 \mathrm{~mm}$.

larger than the paracone; straight centrocrista, large conules and conuloids, more inflated and developed protocone, and absent metacingulum (Figure 2). The M3 (DGM 808-M and MCT 2799-M) is more mesiodistally compressed than M2, but less compressed than $\mathrm{M} 1$; shows a larger $\mathrm{StB}$, single and conical StC, flattened and reduced StD and StE; there is a small supernumerary cusp between $\mathrm{StA}$ and $\mathrm{StB}$, small StA; the preparacrista is moderately developed and contacts the $\mathrm{StA}$; the ectoflexus is deeper than that of M2; the paracone is pyramidal in shape and slightly twisted, while the metacone is rounded; the metacone is taller and broader than the paracone, straight centrocrista; there is a developed parastylar shelf subequal in width to the metastylar shelf; conules and conuloids are inflated and enlarged; the protocone is more inflated and wider; both paracingulum and metacingulum are reduced (Figure 2). The specimen MCT 2799-M differs from the type specimen in the lesser mesiodistal compression of protocone and talon, greater development of protoconal posterobasal expansion, metacone more labially compressed, and greater development of postmetacrista (Figure 3C1-2). The M4 (DGM 808-M and MCT 2800-M) differs from M1-3 in the evident mesiodistal compression, developed metacingulum, paracone more twisted than M1-3, paracone evidently larger than the metacone, parastylar shelf wider than the metastylar shelf, merged StB and 'twinned' cusp to $\mathrm{StB}$, tiny StD, and more compressed protocone (Figure 2). The specimen MCT 2800-M differs from DGM 808-M in having a more developed parastylar shelf and a less developed metaconule (Figure 3A1-3). 


\section{PHYLOGENETIC ANALYSIS}

The results found 36 most parsimonious trees (trees score $=2901 ; \mathrm{CI}=0.300 ; \mathrm{HI}=0.700 ; \mathrm{RI}=0.668)($ Figure 5$)$. Austropediomys marshalli gen. et sp. nov. is recovered as a pediomyoid more closely related to the Pediomyidae than to Aquiladelphidae based on the following synapomorphies: enlarged StA (character $7^{\circ}$ ), vestigial mesiolingual crest of StB $\left(14^{1}\right)$, preparacrista oriented to StA $\left(39^{1}\right)$.

Monodelphopsis travassosi is regarded as a member of the Didelphimorphia, and not as a pediomyoid, as previously speculated (see Marshall, 1987). The phylogenetic analysis recovered "Protolambda" clemensi as an independent taxon from Protolambda, contrary to Davis (2007), who proposed the inclusion of this taxon as a species of Protolambda. The phylogenetic analysis supports the validity of the Pediomyoidea as including Pediomyidae and Aquiladelphidae, as proposed by Davis (2007), with the inclusion of Austropediomys gen. nov. However, the analysis does not support Glasbiidae as a Pediomyoidea, as proposed by Davis (2007), but instead as a member of the Didelphimorphia. The analysis also supports the inclusion of Iqualadelphis as a pediomyoid, as proposed by Williamson et al. (2012, 2014), but contrary to Davis (2007) (Figure 5). Dakotadens + Iugomortiferum are recovered in our analysis as the sister group of the Pediomyoidea (Figure 5). The Pediomyiodea and Stagodontidae + Pariadens are recovered as sister groups, which support the validity of Archimetatheria, as proposed by Szalay (1994).

\section{DISCUSSION}

\section{Dental homologies: conuloids among the Pediomyoidea}

The identification of 'conular-like' structures lingual to the para- and metaconule in the upper molars of the Pediomyoidea is a crucial aspect of the analysis; herein, these structures are named as 'conuloids': paraconuloid and metaconuloid (Figure 6) (character $\left.77^{1}\right)$. These new recognized features are identified as an additional pair of 'conular-like' structures associated with the pre- and the postprotocrista, being placed lingual to the para- and metaconule on the upper molars of Austropediomys marshalli gen. et sp. nov. and other pediomyoids.

Austropediomys marshalli gen. et sp. nov. shows these structures in M2-4 (Figure 2); "Protolambda" clemensi, Pediomys and Aquiladelphis show conuloids in M1-4. Protolambda shows only traces of them on M1-3, but identifiable conuloids in some M4 (see UCMP 47283, left M4 of Protolambda florencae figured in Davis (2007) as fig. 11D1). Leptalestes shows only traces of these structures in M1-4. The presence of conuloids is hard to identify in pediomyids and aquiladelphids due to their weak development, being these structures easily "lost" in upper molars with some degree of wear.

The Aquiladelphidae shows weakly or incipiently developed conuloids, which are not "independent" (see discussion later) from the pre- and postprotocrista. In aquiladelphids, these 'conular-like' structures are tiny and barely seen even in little worn teeth, as discussed. Nevertheless, preserved upper molars with few signs of wear allow the identification of these structures (e.g. UALVP 5522, left M3, and OMNH 66351, left M3, both assigned to Aquiladelphis incus; UALVP 29677, left M1 of Apistodon exiguus). The Pediomyidae also presents merged conuloids with the pre- and postprotocrista, which are as developed as those of aquiladelphids in M1-3, but are slightly larger in some M4. The conuloids of aquiladelphids and pediomyids are smaller than the conules. The conuloids of Austropediomys are also merged with the pre- and postprotocrista, but they are more inflated and enlarged than those of any other metatherian, an autapomorphy of this taxon.

"Protolambda" clemensi shows its conuloids set apart from the pre- and postprotocrista due to the presence of a developed notch, an autapomorphy of this taxon. "Protolambda" clemensi differs from other pediomyoids, including Protolambda, in the remarkable development of metaconuloid crests, which show the largest degree of development among pediomyoids, an autapomorphy of this taxon. The conuloids of Austropediomys and "Protolambda" clemensi are quite more developed than those of aquiladelphyids and pediomyids, being subequal or nearly subequal in size to the para- and metaconule; however, both taxa differ in the merging of the conuloids with the pre- and postprotocrista, as discussed. The presence of large conuloids separated from pre- and postprotocrista supports "Protolambda" clemensi as an independent taxon from Protolambda, contrary to Davis (2007).

In pediomyoid upper molars with some degree of wear, the conuloids are normally identified as heavy, wide and elongated pre- or postprotocrista (Figure 3C1). Goin \& Candela (2004, p. 40-41) described the conules of Kirutherium paititiensis as: "upper molars with vestigial para- and metaconules that are elongate and partially fused with pre- and postprotocrista, respectively". It could be hypothesized that the heavily wear resulted in the apparently merging of the conules, conuloids and pre- and postprotocrista as a broad and low "pre- and postprotocrista" in Kirutherium. This condition is also identifiable in specimen OMNH 64263, left M2 of Pediomys elegans (figured in Davis, 2007 as fig. 7B1).

The conuloids condition of aquiladelphids indicates that these structures initially represented "inflations" of the preand postprotocrista. Interestingly, Turgidodon (Cifelli, 1990) and Dakotadens Eaton, 1993a, present similar "conuloid-like" structures (Eaton, 1993a; Hunter et al., 2010). Dakotadens morrowi shows a variable number of 'conular-like' structures with different degrees of inflation in the pre- and postprotocrista, while Turgidodon shows these supernumerary structures only in the postprotocrista (Hunter et al., 2010). Similar to aquiladelphids and pediomyids, Dakotadens and Turgidodon show the conuloids as inflations of the pre- and postprotocrista. The greatest difference of aquiladelphids, Austropediomys gen. nov. and pediomyids (i.e. most of the pediomyoids) from Dakotadens and Turgidodon is the number of conuloids: most of the pediomyoids have a single conuloid in the pre- and postprotocrista, while the other two taxa show a variable number in both the pre- and postprotocrista. The 


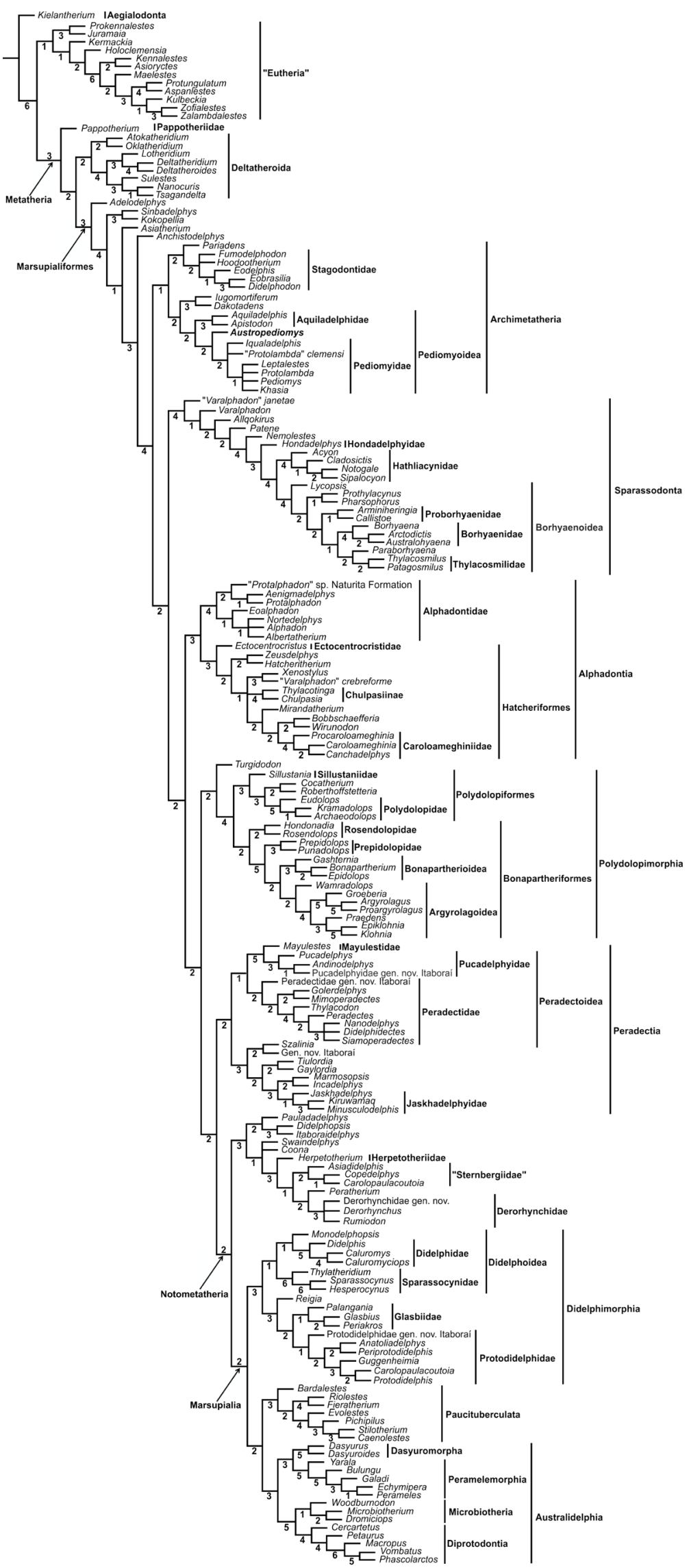

Figure 5. Result of the phylogenetic analysis. Consensus tree of the 36 most parsimonious trees found in the analysis. Austropediomys gen. nov. is highlighted in bold. Numbers below the branches indicate the Bremer Support. 

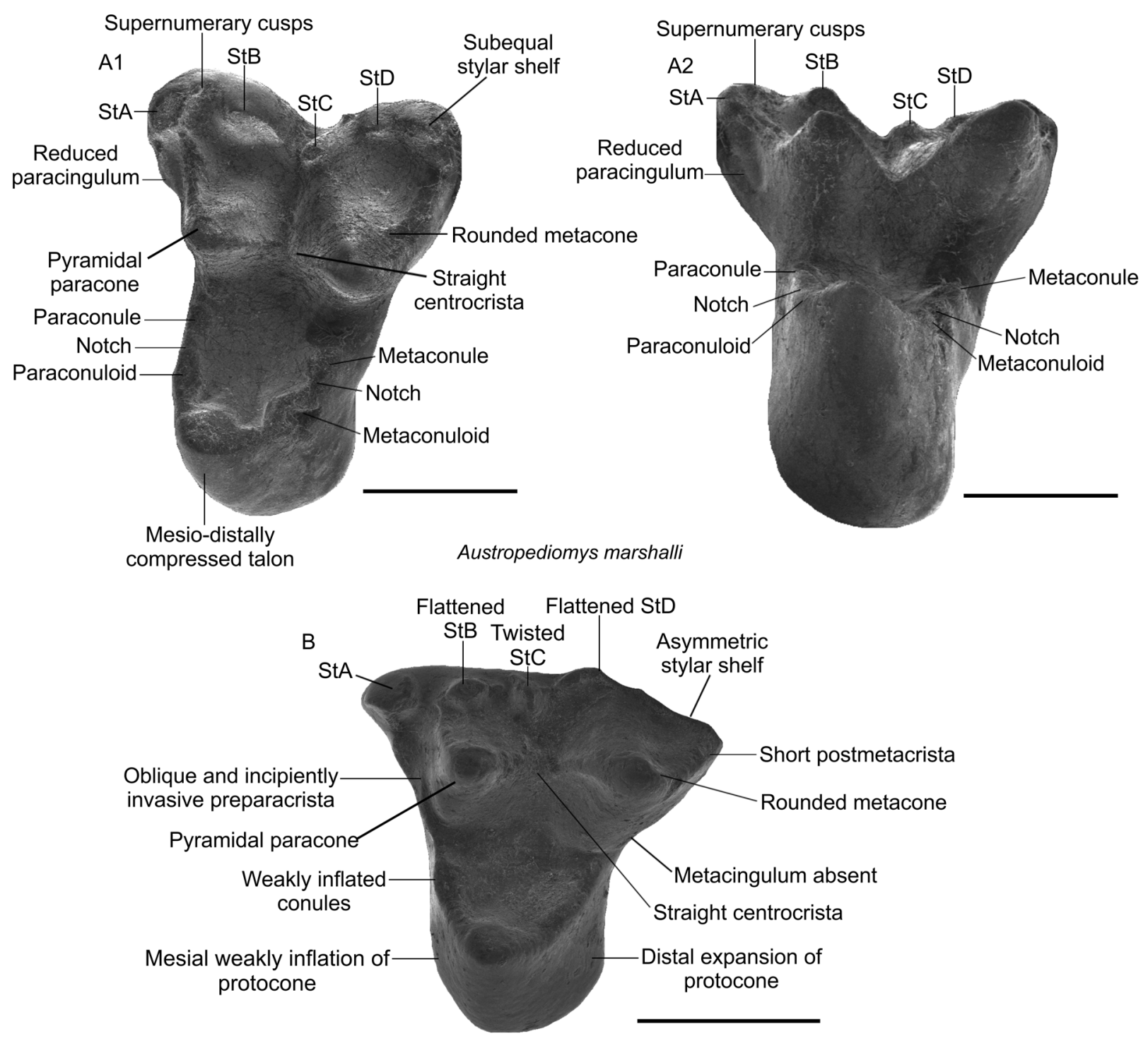

Figure 6. Characters of the upper dentition of Austropediomys marshalli gen. et sp. nov. A1, occlusal, and A2, lingual views of the type specimen (DGM 808-M, a left maxillary fragment with M2-4); B, occlusal view of MCT 2798-M, a LM1, showing the autapomorphies of this species and pediomyoid synapomorphies. Abbreviations: StA, stylar cusp A; StB, stylar cusp B; StC, stylar cusp C; StD, stylar cusp D. Scale bars = $1 \mathrm{~mm}$.

presence of the conuloids in Iugomortiferum could not be confirmed due to wear on the protocristae.

Following the results of the phylogenetic analysis, the conuloids of Turgidodon are not regarded as supporting its monophyly with the Pediomyoidea or Archimetatheria; notwithstanding, the same analysis considered the conuloids of Dakotadens + Iugomortiferum as homologous to those of aquiladelphids, Austropediomys gen.nov. and pediomyids. The same analysis led to the consideration that the conuloids are a synapomorphy of the Pediomyoidea (Figure 5).

\section{Affinities of Austropediomys and other Late Cretaceous- -early Paleogene South American metatherians}

As mentioned above, the phylogenetic analysis recovered Austropediomys marshalli gen. et sp. nov. as a pediomyoid. This result extends the temporal and biogeographical distribution of the Pediomyoidea from the Late Cretaceous of North America (lower Cenomanian - Mussentuchit Member, Cedar Mountain Formation - around $97 \mathrm{Ma}$ - Cifelli et al., 2016) to the Paleogene of South America (lower Eocene Itaboraí Formation - 55-52 Ma - Oliveira \& Goin, 2012; Woodburne et al., 2014) (Figure 7). According to the results, the Pediomyoidea survived after the $\mathrm{K}-\mathrm{Pg}$ boundary (i.e. Late Cretaceous-Paleogene boundary) during the Cenozoic in South America (Marshall, 1987; Marshall et al., 1990; Muizon, 1992; Oliveira \& Goin, 2012), while became extinct in North America (Williamson et al., 2012, 2014; Wilson, 2014). The Santonian oldest fossil records of Aquiladelphis, Apistodon, Iqualadelphis and Leptalestes (Davis, 2007; Eaton, 2013) support a maximum late Santonian origin for the lineage of Austropediomys gen. nov. Notwithstanding, the great diversity of pediomyoids during the late Santonian indicates 


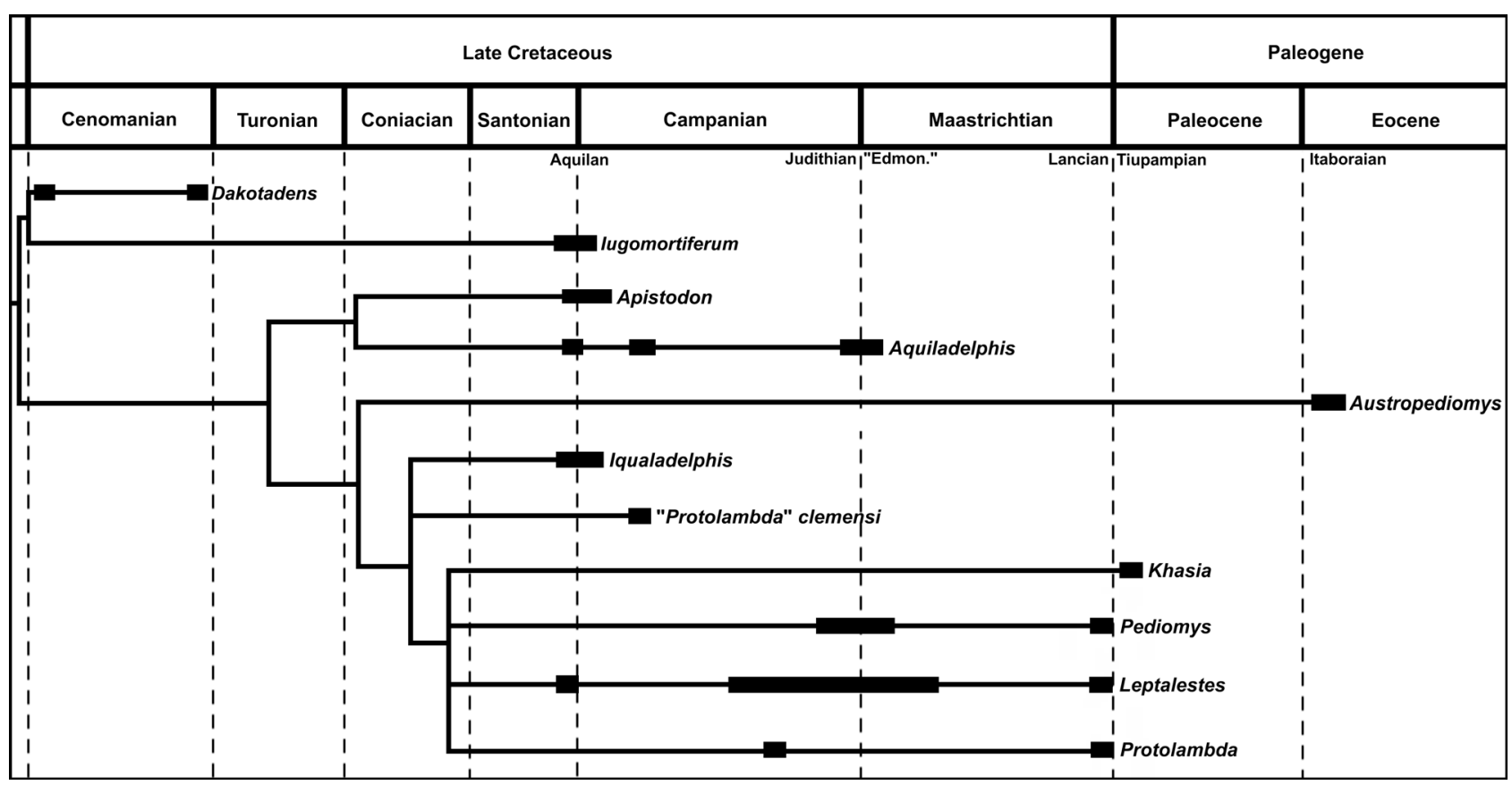

Figure 7. Temporal cladogram of the Pediomyoidea. Phylogeny of the Pediomyoidea calibrated in time, based on the phylogeny present in the Figure 5. The wide bars indicate the recorded temporal range of pediomyoids genera. The NALMAs and SALMAs that present pediomyoids are identified. NALMAs: Aquilan, Judithian, "Edmontonian" and Lancian. SALMA: Tiupampian and Itaboraian.

that the origin and irradiation of these taxa occurred earlier than this time span. The oldest fossil records of Pariadens and Dakotadens in the lower Cenomanian (Mussentuchit Member, Cedar Mountain Formation) support a latest Early Cretaceous or early Late Cretaceous (early Cenomanian) maximum time span for the origin of the Pediomyoidea (Figure 7).

Iqualadelphis was long thought to belong to the Pediomyidae until the comprehensive study performed by Davis (2007), who excluded it from the Pediomyoidea. Notwithstanding, our own analysis is not consistent with Davis' conclusions, supporting the results of Williamson et al. $(2012,2014)$, who recovered Iqualadelphis as a member of the Pediomyoidea.

Khasia cordillerensis is a second taxon whose pediomyid affinities would be discussed in future studies. Since its original description by Marshall \& Muizon (1988), pediomyid affinities were suggested for this taxon from the lower Paleocene of Tiupampa, Bolivia (see also Muizon, 1992). Oliveira \& Goin (2012) and Goin et al. (2016) included Khasia within the Pediomyidae, basically acknowledging that several of its most distinctive features match the basic pediomyoid derived features (sensu Davis, 2007). The phylogenetic analysis of our study supports Khasia as a pediomyid. In any case, it seems clear that Khasia derives from a North American ancestor. The presence of a ?pediomyoid (Khasia?) lower molar in Laguna Umayo Basin (upper Paleocene-lower Eocene - Sigé et al., 2004; Gelfo \& Sigé, 2011) of Peru may also add evidence for a Late Cretaceous, transcontinental dispersal event from North to South America, probably during the latest Maastrichtian.

\section{Paleobiogeographic implications}

The phylogenetic analysis also supports the idea that other South American taxa belong to lineages that had their origins in North America: Sparassodonta (Varalphadon, Carneiro, 2018), Eobrasilia (Stagodontidae, Carneiro \& Oliveira, 2017a), several South American Hatcheriformes (Alphadontia, Carneiro \& Oliveira, 2017b) and Polydolopimorphia (sister group to Turgidodon) and the common ancestor of Peradectia + Notometatheria (sensu Kirsch et al., 1997) (Figure 5). This agrees well with previous hypotheses suggesting multiple origins of South American clades (e.g. Case et al., 2005; Forasiepi, 2009; Goin et al., 2012, 2016; Carneiro \& Oliveira, 2017a, b; Carneiro, 2018). That is, South American clades were not the result of a single radiation but instead of successive marsupialiform radiations from North America via Caribbean Plate. In words of Case et al. (2005, p. 461), “... typical South American lineages (e.g. didelphimorphians and polydolopimorphians) are not the result of North American peradectian progenitors dispersing into South America at the end of the Cretaceous (Lancian), or at the beginning of the Paleocene (Puercan) and giving rise to the ameridelphian marsupials. Instead, these lineages, and predictably others as well, had their origins in North America (probably in more southerly latitudes) and then dispersed into South America by the end of the Cretaceous".

Late Cretaceous-Paleogene faunal correlations between North and South America were subject of several previous studies (Bonaparte, 1984; Case \& Woodburne, 1986; Case et al., 2005; Pascual, 2006; Pascual \& Ortiz-Jaureguizar, 2007; Goin et al., 2016; Carneiro \& Oliveira, 2017a, b; 
Carneiro, 2018). Some of these studies suggested a late Maastrichtian (around 66-69 Ma) biotic interchange between North and South America (the FABI, or first American Biotic Interchange of Goin et al., 2012). This time span is consistent with several strong sea-level lowstands (Haq, 2014) that happened during the second half of the Maastrichtian: 69-70, 68-69, and 66-67 Ma.

During the Late Cretaceous, current Central America was a place of intense volcanic activity, and recent geological models reconstructed this area as a set of islands (i.e. 'Aves Ridge' concept) (Pindell, 1994). Previous studies considered the 'Aves Ridge' and adjacent Cuba in the Campanian and especially in the Maastrichtian as one of the best pathway candidates for the dispersal rout between Americas (Woodburne \& Case, 1996; Case et al., 2005). Other studies (Eaton, 1993b; Carneiro \& Oliveira, 2017a, b; Carneiro, 2018) associated the insular Caribbean and the strong sea-level regressions to an 'island-hopping' or sweepstakes dispersal model (sensu Simpson, 1940) for metatherians. The strong sea-level regressions during the Late Cretaceous probably allowed, not one but several dispersals of metatherians (and of other vertebrates as well) from island to island, while the sea-level transgressions isolated the Caribbean islands.

\section{CONCLUSIONS}

The description of Austropediomys marshalli gen. et sp. nov. corroborates previous hypotheses regarding the presence of pediomyoids metatherians in South America. This increases the paleobiogeographic and temporal range of the Pediomyoidea, as previously understood.

The presence of strong sea-level lowstands during the Late Cretaceous seems to be a major factor in the biogeography of the group, probably allowing the arrival of pediomyoids in South America via the Caribbean during the latest Late Cretaceous. The results of the phylogenetic analysis support a North American origin for the lineage of Austropediomys gen. nov.

The arrival of North American metatherians to South America was, probably, neither a single dispersal event nor involving a single lineage. The results of the phylogenetic analysis supports the idea that several non-related lineages were part of this faunal dispersals: Sparassodonta, Archimetatheria (Pediomyoidea and Stagodontidae), Alphadontia (Hatcheriformes) and Polydolopimorphia. Also, that the radiation of Marsupialia, as well as that of "basal" australidelphians, was a strictly South American event.

\section{ACKNOWLEDGMENTS}

We thank the Universidade Federal de Pernambuco for providing the equipment and laboratories that allowed our analyses; the Laboratório de Paleontologia e Paleoecologia da Sociedade de História Natural, Torres Vedras, Portugal, in which the first author is affiliated; C. de Muizon and G. Billet from the Muséum National d'Histoire Naturelle; R.
Machado and R. Costa from the Departamento Nacional de Produção Mineral (DNPM); P. Myers from the Museum of Zoology - University of Michigan; S. Jiquel from the Institut des Sciences de l'Évolution - Université Montpellier; and R.L. Cifelli and J. Cohen from Oklahoma Museum of Natural History for providing photos, articles and/or information about the collections and specimens from North America; two anonymous reviewers of an earlier version of this manuscript; the Willi Henning Society for sponsoring the construction and allowing the free use of TNT. Finally, we thank the Fundação de Amparo à Ciência e Tecnologia do Estado de Pernambuco (FACEPE) for supporting this project.

\section{REFERENCES}

Abello, M.A. 2013. Analysis of dental homologies and phylogeny of Paucituberculata (Mammalia: Marsupialia). Biological Journal of the Linnean Society, 109:441-465. doi:10.1111/bij.12048

Beck, R.M.D. 2017. The skull of Epidolops ameghinoi from the Early Eocene Itaboraí Fauna, southeastern Brazil, and the affinities of the extinct Marsupialiform order Polydolopimorphia. Journal of Mammalian Evolution, 24:373-414. doi:10.1007/s10914016-9357-6

Bergqvist, L.P.; Mansur, K.; Rodrigues, M.A.; Rodrigues-Francisco, B.H.; Perez, R. \& Beltrão, M.C. 2009. Bacia São José de Itaboraí, RJ. Berço dos mamíferos no Brasil. In: M. Winge; C. Schobbenhaus; C.R.G. Souza; A.C.S. Fernandes; M. BerbertBorn \& E.T. Queiroz (eds.) Sitios Geológicos e Paleontológicos do Brasil, CPRM, p. 1-15.

Bonaparte, J.F. 1984. El intercambio faunístico de vertebrados continentales entre América del Sur y del Norte a fines del Cretácico. In: CONGRESO LATINOAMERICANO DE PALEONTOLOGÍA, 3, 1984. Memória, UNAM, p. 438-450.

Carneiro, L.M. 2018. A new species of Varalphadon (Mammalia, Metatheria, Sparassodonta) from the upper Cenomanian of southern Utah, North America: phylogenetic and biogeographic insights. Cretaceous Research, 84:88-96. doi:10.1016/j. cretres.2017.11.004

Carneiro, L.M. \& Oliveira, É.V. 2017a. Systematic affinities of the extinct metatherian Eobrasilia coutoi Simpson, 1947, a South American early Eocene Stagodontidae: implications for "Eobrasiliinae". Revista Brasileira de Paleontologia, 20:355372. doi:10.4072/rbp.2017.3.07

Carneiro, L.M. \& Oliveira, É.V. 2017b. The Eocene South American metatherian Zeusdelphys complicatus is not a protodidelphid but a hatcheriform: paleobiogeographic implications. Acta Palaeontologica Polonica, 62:497-507. doi:10.4202/app.00351.2017

Carpenter, K. 2014. Where the sea meets the land - the unresolved problem in Utah. In: J.S. Maclean; R.F. Biek \& J.E. Huntoon (eds.) Geology of Utah's Far South, Salt Lake City, Utah Geological Association, p. 357-372 (Publication 43).

Case, J.A.; Goin, F.J. \& Woodburne, M.O. 2005. "South American" marsupials from the Late Cretaceous of North America and the origin of marsupial cohorts. Journal of Mammalian Evolution, 12:461-494. doi:10.1007/s10914-005-7329-3

Case, J.A. \& Woodburne, M.O. 1986. South American marsupials: a successful crossing of the Cretaceous-Tertiary boundary. Palaios, 1:413-416. doi:10.2307/3514478 
Cifelli, R.L. 1990.Cretaceous mammals of southern Utah. I. Marsupials from the Kaiparowits Formation (Judithian). Journal of Vertebrate Paleontology, 10:295-319. doi:10.1080/0272463 4.1990 .10011816

Cifelli, R.L.; Cohen, J.E. \& Davis, B.M. 2016. New tribosphenic mammals from the Mussentuchit Local Fauna (Cedar Mountain Formation, Cenomanian), Utah, USA. In: R.L. Cifelli \& L. Fostowicz-Frelik (eds.) Legacy of the Gobi Desert: papers in memory of Zofia Kielan-Jaworowska, Warsaw, Instytut Paleobiologii, p. 67-81 (Palaeontologia Polonica 67).

Clemens, W.A. 1966. Fossil mammals of the type Lance Formation, Wyoming. Part II. Marsupialia. Berkeley, University of California, 122 p. (Publications in Geological Sciences 62).

Davis, B.M. 2007. A revision of "pediomyid" marsupials from the Late Cretaceous of North America. Acta Palaeontologica Polonica, 52:217-256.

Eaton, J.G. 1993a. Therian mammals from the Cenomanian (upper Cretaceous) Dakota Formation, southwestern, Utah. Journal of Vertebrate Paleontology, 13:105-124. doi:10.1080/02724634. 1993.10011491

Eaton, J.G. 1993b. Marsupial dispersal. National Geographic Research \& Exploration, 9:436-443.

Eaton, J.G. 2006. Late Cretaceous mammals from Cedar Canyon, southwestern Utah. In: S.G. Lucas \& R.M. Sullivan (eds.) Late Cretaceous vertebrates from the western interior, Albuquerque, New Mexico Museum of Natural History and Science, 30 p. (Bulletin 35).

Eaton, J.G. 2013. Late Cretaceous mammals from Bryce Canyon National Park and Vicinity, Paunsaugunt Plateau, southwestern Utah. In: A.L. Titus \& M.A. Loewen (eds.) At the top of the Grand Staircase: the Late Cretaceous of southern Utah, Indiana University Press, p. 329-369.

Forasiepi, A.M. 2009. Osteology of Arctodictis sinclairi (Mammalia, Metatheria, Sparassodonta) and phylogeny of Cenozoic metatherian carnivores from South America. Buenos Aires, Museo Argentino de Ciencias Naturales, 174 p. (Monografías 6).

Forasiepi, A.M.; Babot, M.J. \& Zimicz, N. 2015. Australohyaena antiqua (Mammalia, Metatheria, Sparassodonta), a large predator from the Late Oligocene of Patagonia. Journal of Systematic Palaeontology, 13:503-525. doi:10.1080/14772019.2014.92 6403

Gelfo, J.N. \& Sigé, B. 2011. A new didolodontid mammal from the late Paleocene-earliest Eocene of Laguna Umayo, Peru. Acta Palaeontologica Polonica, 56:665-678. doi:10.4202/ app.2010.0067

Goin, F.J. \& Candela, A.M. 2004. New Paleogene marsupials from the Amazon basin of eastern Peru. In: K.E. Campbell (ed.) The Paleogene Mammalian Fauna of Santa Rosa, Amazonian Peru, Natural History Museum of Los Angeles County, p. 15-60.

Goin, F.J.; Gelfo, J.N.; Chornogubsky, L.; Woodburne, M.O. \& Martin, T. 2012. Origins, radiations, and distribution of South American mammals: from greenhouse to icehouse worlds. In: B.D. Patterson \& L.P. Costa (eds.) Bones, clones, and biomes: an 80-million-year history of recent Neotropical mammals, The University of Chicago Press., p. 20-50. doi:10.7208/ chicago/9780226649214.003.0003

Goin, F.J.; Woodburne, M.O.; Zimicz, A.N.; Martin, G.M. \& Chornogubsky, L. 2016. Dispersal of vertebrates from between the Americas, Antarctica, and Australia in the Late Cretaceous and Early Cenozoic. In: P. Blondel; E. Guilyardi; J. Rabassa \& C.
Horwood (eds.) A brief history of South American Metatherians, Springer, p. 77-124. doi:10.1007/978-94-017-7420-8_3

Goloboff, P.A. \& Catalano, S.A. 2016. TNT version 1.5, including a full implementation of phylogenetic morphometrics. Cladistics, 32:221-238. doi:10.1111/cla.12160

Haq, B.U. 2014. Cretaceous eustasy revisited. Global and Planetary Change, 113:44-58. doi:10.1016/j.gloplacha.2013.12.007

Hunter, J.P.; Heinrich, R.E. \& Weishampel, D.B. 2010. Mammals from the St. Mary River Formation (Upper Cretaceous), Montana. Journal of Vertebrate Paleontology, 30:885-898. doi:10.1080/02724631003763490

Kirsch, J.W.A.; Lapointe, F. \& Springer, M.S. 1997. DNAhybridisation studies of marsupials and their implication for metatherian classification. Australian Journal of Zoology, 45:211-280. doi:10.1071/ZO96030

Ladevèze, S. \& Muizon, C. 2010. Evidence of early evolution of Australidelphia (Metatheria, Mammalia) in South America: phylogenetic relationships of the metatherians from the Late Palaeocene of Itaboraí (Brazil) based on teeth and petrosal bones. Zoological Journal of the Linnean Society, 159:746-784. doi:10.1111/j.1096-3642.2009.00577.x

Luo, Z.; Yuan, C.; Meng, Q. \& Ji, Q. 2011. A Jurassic eutherian mammal and divergence of marsupials and placentals. Nature, 476:442-445. doi:10.1038/nature10291

Marshall, L.G. 1987. Systematics of Itaboraian Age "opossum-like" Marsupials. In: M. Archer (ed.) Possums and Opossums: studies in evolution, The Royal Zoological Society of New South Wales, p. 91-160.

Marshall, L.G.; Case, J. \& Woodburne, M.O. 1990. Phylogenetic relationships of the families of marsupials. Current Mammalogy, 2:433-505.

Marshall, L.G. \& Muizon, C. 1988. The dawn of the age of mammals in South America. National Geographic Research, 4:23-55.

Muizon, C. 1992. La fauna de Mamiferos de Tiupampa (Paleoceno Inferior, Formacion Santa Lucia), Bolivia. In: R. Suarez-Soruco (ed.) Fosiles y facies de Bolivia - I Vertebrados, Santa Cruz, YPFB, p. 575-624 (Revista Técnica 12).

Muizon, C.; Billet, G.; Argot, C.; Ladevèze, S. \& Goussard, F. 2015. Alcidedorbignya inopinata, a basal pantodont (Placentalia, Mammalia) from the early Palaeocene of Bolivia: anatomy, phylogeny and palaeobiology. Geodiversitas, 37:397-634. doi:10.5252/g2015n4al

Oliveira, É.V. 1998. Taxonomia, filogenia e paleobiogeografia de marsupiais "poliprotodontes" do mesopaleoceno da Bacia de Itaboraí, Brasil. Programa de Pós-Graduação em Geociências, Universidade Federal do Rio Grande do Sul, Tese de Doutorado, 327 p.

Oliveira, É.V. \& Goin, F.J. 2011. A reassessment of bunodont metatherians from the Paleogene of Itaboraí (Brazil): systematics and age of the Itaboraian SALMA. Revista Brasileira de Paleontologia, 14:105-136. doi:10.4072/rbp.2011.2.01

Oliveira, É.V. \& Goin, F.J. 2012. Metatérios do início do Paleógeno no Brasil: diversidade e afinidades. In: N.C. Cáceres \& E.L.A. Monteiro-Filho (eds.) Os Marsupiais do Brasil, Universidade Federal do Mato Grosso do Sul, p. 275-310.

Oliveira, É.V.; Zimicz, N. \& Goin, F.J. 2016. Taxonomy, affinities, and paleobiology of the tiny metatherian mammal Minusculodelphis, from the early Eocene of South America. Science of Nature, 103:6. doi:10.1007/s00114-015-1331-2 
Pascual, R. 2006. Evolution and geography: the biogeographic history of South American land mammals. Annals of the Missouri Botanical Garden, 93:209-230. doi:10.3417/00266493(2006)93[209:EAGTBH]2.0.CO;2

Pascual, R. \& Ortiz-Jaureguizar, E. 2007. The Gondwanan and South American episodes: two major and unrelated moments in the history of the South American mammals. Journal of Mammalian Evolution, 14:75-137. doi:10.1007/s10914-007-9039-5

Paula Couto, C. 1952. Fossil Mammals from the beginning of the Cenozoic in Brazil Marsupialia: Didelphidae. American Museum Novitates, 1567:1-26.

Pindell, J.L. 1994. Evolution of the Gulf of Mexico and the Caribbean. In: S.K. Donovan \& T.A. Jackson (eds.) Caribbean geology: an introduction, The University of West Indies Publishers Association, p. 13-39.

Sigé, B. 1972. La faunule de Mammifères du Crétacé supérieur de Laguna Umayo (Andes péruviennes). Bulletin du Muséum National d'Histoire Naturelle, 19:375-405.

Sigé, B.; Sempere, T.; Butler, R.F.; Marshall, L.G. \& Crochet, J. 2004. Age and stratigraphic reassessment of the fossil-bearing Laguna Umayo red mudstone unit, SE Peru, from regional stratigraphy, fossil record, and paleomagnetism. Geobios, 37:771-794. doi:10.1016/j.geobios.2003.06.006

Simpson, G.G. 1927. Mesozoic Mammalia, VIII; Genera of Lance mammals other than multituberculates. American Journal of Science, 14:121-130. doi:10.2475/ajs.s5-14.80.121

Simpson, G.G. 1940. Mammals and land bridges. Journal of the Washington Academy of Sciences, 30:137-163.

Szalay, F.S. 1994. Evolutionary history of the marsupials and an analysis of osteological characters. New York, Cambridge University Press, $481 \mathrm{p}$.

Vullo, R.; Gheerbrant, E.; Muizon, C. \& Néraudeau, D. 2009. The oldest modern therian mammal from Europe and its bearing on stem marsupial paleobiogeography. Proceedings of the National Academy of Sciences of the United States of America, 106:19910-19915. doi:10.1073/pnas.0902940106
Williamson, T.E.; Brusatte, S.L.; Carr, T.D.; Weil, A. \& Standhardt, B.R. 2012. The phylogeny and evolution of CretaceousPalaeogene metatherians: cladistic analysis and description of new early Palaeocene specimens from the Nacimiento Formation, New Mexico. Journal of Systematic Palaeontology, 10:625-651. doi:10.1080/14772019.2011.631592

Williamson, T.E.; Brusatte, S.L. \& Wilson, G.P. 2014. The origin and early evolution of metatherian mammals: the Cretaceous record. ZooKeys, 465:1-76. doi:10.3897/zookeys.465.8178

Wilson, G.P. 2014. Mammalian extinction, survival, and recovery dynamics across the Cretaceous-Paleogene boundary in northeastern Montana, USA. In: G.P. Wilson; W.A. Clemens; J.R. Horner \& J.H. Hartman (eds.) Through the end of the Cretaceous in the type locality of the Hell Creek Formation in Montana and adjacent areas, Boulder, The Geological Society of America, p. 365-392 (Special Papers 503). doi:10.1130/2014.2503(15)

Wilson, P.G.; Ekdale, E.G.; Hoganson, J.W.; Calede, J.J. \& Linden, A.V. 2016. A large carnivorous mammal from the Late Cretaceous and the North American origin of marsupials. Nature Communications, 7:13734. doi:10.1038/ncomms 13734

Woodburne, M.O. \& Case, J.A. 1996. Dispersal, vicariance, and the Late Cretaceous to Early Tertiary land mammal biogeography from South America to Australia. Journal of Mammalian Evolution, 3:121-161. doi:10.1007/BF01454359

Woodburne, M.O.; Goin, F.J.; Raigemborn, M.S.; Heizler, M.; Gelfo, J.N. \& Oliveira, É.V. 2014. Revised timing of the South American early Paleogene land mammals ages. Journal of South American Earth Sciences, 54:109-119. doi:10.1016/j. jsames.2014.05.003

Received in 01 January, 2018; Accepted in 01 June, 2018. 